\title{
Exploring Education Character Thought of Ki Hajar Dewantara and Thomas Lickona
}

\author{
Asnawan \\ Institut Agama Islam Al Falah As Sunniyyah Kencong Jember, Indonesia
}

Corresponding Author: Asnawan, $\otimes$ asnawan@inaifas.ac.id

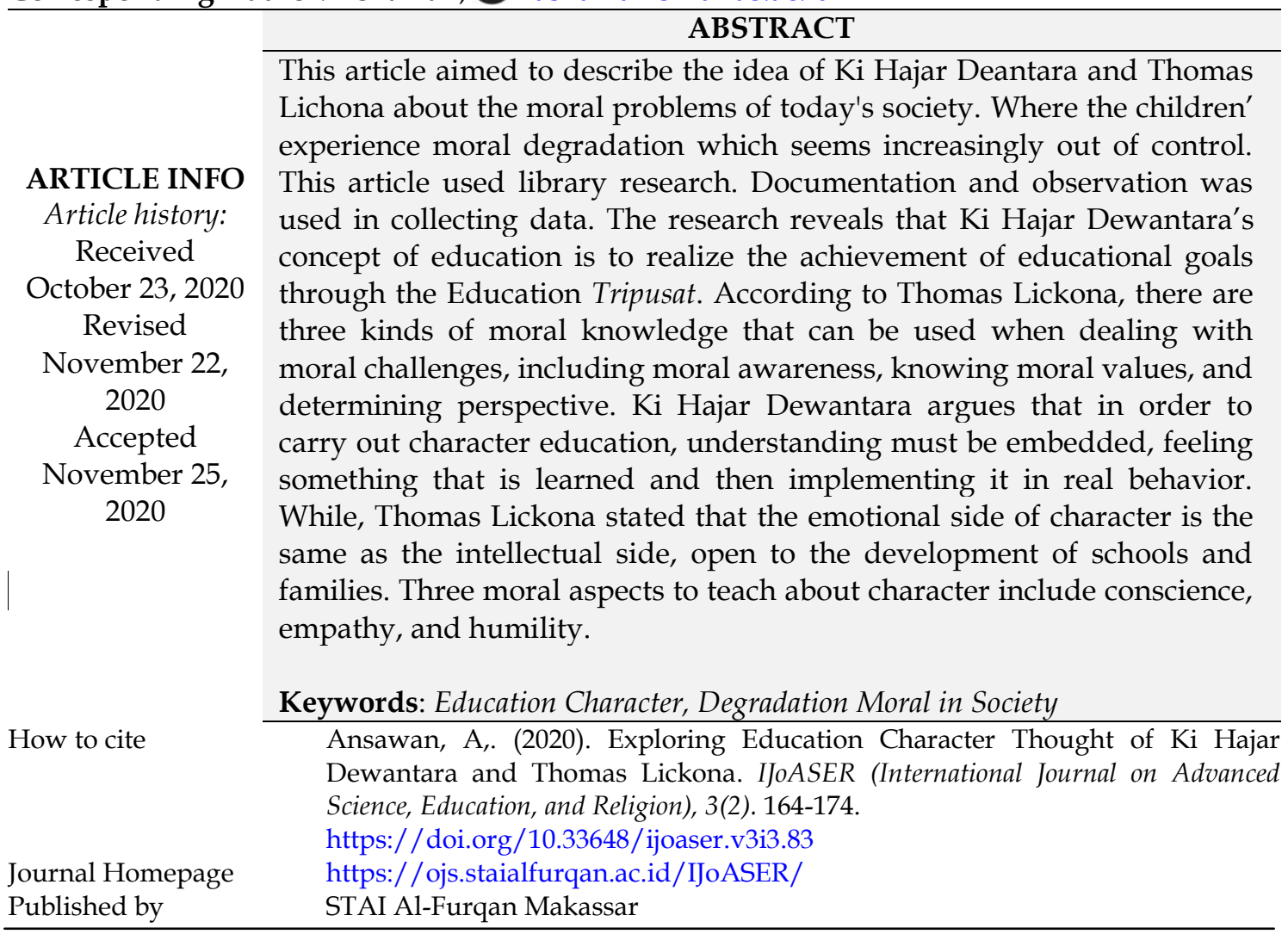

\section{INTRODUCTION}

Knowledge and technology are at the forefront that must be prioritized in the era of globalization. Japan, South Korea, Singapore, and Malaysia have been running headto-head to catch up and transform themselves not only as passive spectators, but also as creative actors who play an active role in the rigorous process of globalization (Jamal Ma'ruf Asmani, 2013). The rapid development of science, information technology and communication. nowadays it has brought big changes in various sectors of human life. This has had a major influence on people's attitudes and behavior, including children.

Children, who basically have an imitation and curiosity, are also carried away in the flow of globalization and advances in science, information technology and communication (Oudeyer et al., 2016; Pérez, 2016). The information and communication technology revolution is a big challenge for the world of education in Indonesia. If we are only passive and stagnant, Indonesia's education world will soon be left behind from neighboring countries. We will not be able to keep up with the changing world that is going on so fast. Therefore, there is no other way for our world 
of education, except to "brush up your sleeves", devote all your abilities, and make use of all the potential that exists to catch up in the field of information and communication technology in the current era of globalization.

Religion which is an important factor in shaping the character of students is only placed in a very minimal position, and does not become the foundation of all aspects. Our education system only relies on a way of thinking that contains a curriculum, not on character building (Yudabangsa, 2020; Amrizal et al., 2020), students of educational institutions in Indonesia fail to act as social institutions capable of building the character of the Indonesian nation in accordance with thenormative values nationalaspired. The emergence of many destructive cases. The national context, for example there are sentiments between ethnic groups, tribal disputes, drug cases, student fights, violence against children, shows the weak character of the Indonesian nationality (Jumadi \& Nurlela 2017; Amri, 2020). It would not be too wrong if theiots which led to the symptom of national disintegration eventually came from weak education in shaping the character of the nation. And education is a pillar in shaping the character of the nation (Kristiawan et al., 2017). As if in the world of education, honesty has become a rare item. For example, the loss of honesty among schools, such as the number of children cheating in class when tests are in progress, the loss of honesty in the community such as corruption and collusion (Prasetiawati, 2018). all of this is because today's society is more concerned with general education than religious education in the application of daily life. From this case, it can be seen that the Indonesian nation is currently experiencing a moral and ethical crisis which is worrying and which is still very difficult to control (Harahap, 2017; Manshuruddin, 2019). The condition of the moral crisis indicates that the religious and moral knowledge obtained in school does not have an impact on changing attitudes and behavior ofsociety Indonesian.

From several views on characters as above, this research was essential to be conducted, because Lickona' opinion expressed that character is a reliable inner disposition to respond to situations in a morally good way, which means that the innermost character responds to situations in a good and moral way. In Lickona's view, character means an innermost character that can be relied on to respond to situations in amanner morally good. Furthermore, Lickona added, "character so conceived has three interrelated parts: moral knowing, moral feeling, and moral behavior (Marzuki, 2015). This means that character is composed of three interrelated parts, namely knowledge of morals, moral feelings, and moral behavior. So, character consists of three main, interconnected parts, namely knowledge of morals, moral feelings, and moral behavior. Good character consists of knowing good things, wanting good things, and doing good things - habits in thinking, habits in heart and habits in acting.

\section{METHODS}

This research had employed a qualitative research with case research library. Because this study seeks to describe and analyze phenomena, events, social activities, attitudes, and perceptions of a person or group (Killam \& Heerschap, 2013; Conway, 2014). This research was conducted during April 2020. The use of this descriptive research design in the research aims to find out the patterning Ki Hajar Dewantara and Thomas Lickona's thought. Data collection is a procedure carried out systematically and standardized to be able to obtain data. In this regard, based on the type of research and the types of data sources used and those that have been determined, the data collection technique in this study is to use a documentation and observation. The data 
used in this study are primary, i.e. data obtained directly by researchers and secondary data, i.e. data obtained from relevant research results and other information.

The researcher conducted a pure literary study of pure books written directly by Ki Hajar Dewantara and Thomas Lickona as the main data source and ontexts other supporting. This research uses a qualitative approach. The reason the researcher chose this research library study was because the research problem could only be answered through library research and this research could not possibly expect the data from field research (Sugiyono, 2016). In this context the researcher is dealing directly with descriptive texts or data and not directly dealing with the field and eye witnesses (Mastika Zed, 2017) The purpose of the researchers choosing this type of research is to provide a brief description of the concept of character education according to Ki Hajar Dewantara and Thomas Lickona.

Researchers also want to explore research data directly and which have become the fruit of this research, namely the concept of character education according to the thoughts of Ki Hajar Dewantara and Thomas Lickona. Data Analysis Techniques After the data collected both from print andmedia, electronic then the next step is to analyze the data using content analysis(contentanalysis), which attempts to interpret the content and idea or ideas of Ki Hajar Dewantar and Thomas Lickona the concept of character education.

\section{RESULT AND DISCUSSION}

Transformation of Character Education Education that brings direct transformation means that the purpose of carrying out education is to bring about transformation. A transformation must start from an awareness of Allah's saving grace and only by faith with the guidance of Allah SWT. we can undergo transformation. However, this understanding will not be able to answer general problems and issues about education that bring about transformation. Transformation in this case is not just for bringing about change.

Human morals can be shaped by various internalinfluences or external. Internal influence resides in humans or character (a basic trait that has become innate since humans are born), although external influences can also shape certain characteristics. The environment, livelihoods, food, daily interactions with friends, family, relatives, and so on that are always involved in human life can continuously shape human character (Hamdani \& Beny, 2015).

From the explanation above, it can be concluded that the transformation conveyed through education is not only on the surface but begins with a fundamental thing, namely belief that will determine abehavior person'sand form a habit. Then build the character that will appear on the surface as a result of the transformation process. Transformation is a process of gradual change so that it reaches the ultimate stage, changes are made by responding to the influence of external and internal elements that will lead to changes from previously known forms, management of education for the common interest can unravel the tangled threads of Indonesian society.

Based on the Regulation of the Minister of National Education No. 22, 23 and 24 of 2006. Various efforts to establish cooperation in the form of training, workshops, teacher community formation, joint research and other forms that lead to information exchange and innovation are needed to improve teachers' ability to understand models, methods, and content in curriculum preparation. . Respecting each other's 
roles among school administrators, community leaders, education experts, and the bureaucracy is expected to accelerate the process of improving the quality of education.

Therefore clearly the task and purpose of education is to bring change (to transform) not to conform (to conform). The transformation process begins with restoringvalues divineto humans with the guidance of the Qur'an and Sunnah and building the growth of faith so that it is renewed every day and so that they can become human beings with noble morals (insan kamil) (Salahudin \& Alkrienciehie, 2013; Cahyono et al., 2017). Elkind and sweet said that character education is a deliberate effort to help understand humans, care and the core of ethical / moral values. Where we think about the kinds of characters we want our children to have, it is clear that we want them to be able to judge what truth is, care deeply about what truth is, and then do what they believe to be true, even in the face the stress of without and under temptation (Heri Gunawan, 2014).

Character education is an intellectual result thata lot has contributedof thoughts from classical figures, such as from Lawrence Kohlberg, FW Foerster, Thomas Lickona, Dhoni Kusuma, Ari Ginanjar Agustin, and Ki Hajar Dewantara.

1. The process of character building or personality consists of three levels, namely: habituation. The aim is to form the physical aspects of the personality, or to give the ability to do and say something (rote knowledge). For example, get used to praying and fasting.

2. Formation of understanding, attitudes and interests. After doing the habituation, then someone is given an understanding or knowledge of the practice that is done and said

3. A sublime spiritual formation. This planting instills the belief that is in the pillars of faith. As a result, someone will go deeper into what is done or said, thereby increasing responsibility for what is done

\section{Internalization of Education Character}

Internalization is appreciation of a teaching, doctrine or value that is embodied in attitudes and behavior. Internalization can also be said to be a process or way of instilling doctrine orvalue normativethat determine educational behavior in accordance with th guidance towards the formation of a dignifiednational personality (character)

The internalization of character education as described above can be realized through and relies on four main pillars that must be built together and cannot be separated, namely:

1. Family as the most important institution in instilling basic values for a person. All value systems are built in the family, including discipline, order, appropriateness, honesty, courtesy, solidarity, ability to communicate and socialize, self-integrity, attitudes of faith, and so on.

2. Schools as formal educational institutions that are responsible for teaching science and technology, skills, and social values. After children enter school, they must be able to adapt to the conditions andrules school that are applicable and formulative. Likewise with a teacher, teachers must be able to overcome all forms of attitudes and character of a child besides they also have to adapt to the demands / conditions of the school. 
3. A place of worship as an educational institution in instilling moral values, honesty, responsibility, ethics, courtesy, manners.

4. The government as anpolicymaker educationwho will be responsible for making educational policies that will produce quality human resources that are superior and characterized.

\section{Transinternalization of Education Character}

Transinternalization of character education is a process of inherently living the values of character education through Islamic education so that it becomes a collective awareness that binds and manifested in ethical rules in empowering humans. In society there are factors that make the humanization process by education difficult or easy. This is due to the inflexibility of the social environment which has a major effect on personality formation. Environmental inflexibility is "the extent to which the environment conflicts withneeds and demands personal". Individuals will live in harmony with their environment as long as the environment is able to meet their needs.

Transinternalization is the integration of structural changes and innovative efforts so that the linkage between the education function and society is maintained in dealing with issues that develop in society by flexibility. Sensitivity and commitment to the development of society itself in realizing the objectives of Islamic education to shape civilization. The need for transinternalization of character education is due to the loss of ethical values from the output of education in society. Manners in society are starting to fade, and there are no more manners. This concerns the entire system of life, both in social, economic, political and cultural relations. The growth of individualism colored the arrogance of behavior without recognizing social care. Education is only meaningful for intellectual youth, and lacks in inculcating attitudes.

The role of education is very strategic because it isbuilder a strongof national integrity. Apart from being influenced by political andfactors economic, education is also influenced by socio-cultural factors, particularly in the aspects of integrity and social resilience.

\section{Concept of Education Character Ki Hajar Dewantara}

Character, moral and culturalhas actually been initiated educationby Ki Hajar Dewantara with three education centers starting from the family environment, the school environment, and the social environment. The school environment (teachers) currently has a very big role in shaping the character of children / students. The role of teachers in the world of modern education is now increasingly complex, not only as teachers, academic educators but also as character, moral and cultural educators for their students.

$\mathrm{Ki}$ Hajar explained that moral education is directed at the formation of national character in accordance with religious values and national culture. He wants the Indonesian people to have advanced attitudes and views on the one hand, but on the other hand, he still stands on the personality as an Indonesian nation that has a distinctive culture and personality, does not imitate or behave westernized and so on (Muthoifi \& Mutohharun, 2015).

Teachers must be role models for their students. A model as well as a mentor of the child / student must be able to manifestbehavior characterwhich includes thought, heart and feeling. The concept of education according to Ki Hajar Dewantara is by applying the "Among System". The "Among 
system" is an educational method used in Tamansiswa, caring for children means giving children freedom to move according to their wishes, but the tutor / teacher will act, even with coercion if the child's wish endangers their safety.

Meanwhile, educational methods that are compatible with the character and culture of the Indonesian people are those that do not use coercive conditions. Because the Indonesian people belong to the eastern nation, a nation that lives in a treasure trove of traditional values in the form of refinement of taste, lives in love, love for peace, brotherhood, order, honesty and politeness in speaking. These values all originate through education from an early age.

1) Ing Ngarsa Sung Tuladha: It means that an educator must always be at the front to set an example. $\mathrm{He}$ is a leader who sets an example in his words and deeds so that his students deserve to be emulated.

2) Ing Madya Mangun Karsa This means that an educator is always in the midst of his students and continuously initiates / motivates his students to work, build intentions, enthusiasm, and fosters ideas so that students are productive in their work.

3) Tut Wuri Handayani This means that an educator always supports and sustains (encourages) his students to work in the right direction for social life. Educators follow their students from behind, give freedom to move and influence them with their strength, if necessary with force and firmness if the freedom given to students is used to deviate and will endanger their lives.

The three concepts of Ki Hajar Dewantara's education are phenomenalable to become the supporting pillars in the success of a teacher in completing character education in Indonesia. According to Ki Hajar Dewantara, an educator must reflect a person he can like and be the best example for his students. An educator must have attitudes and actions that can be carried out by thei students in such a way in the future, both in the school environment, family and community. Students with their innate nature are given freedom or freedom to solve their own problems. So educators only do Tut Wuri Handayani, unless the problems faced by these students endanger themselves, only then do educators take over action on these problems (Henricus Suparlan, 2015).

\section{Education Character According to Thomas Lickona}

According to Thomas Lickona, good character involves three components of character, including moral knowledge, moral feelings, and moral actions. In this case, moral feelings have aroused strong feelings, then these judgments and feelings motivate moral action. Moral judgments and moral feelings clearly influence moral behavior, especially when the two are present together. But here too the effects are reciprocal: the way we behave also affects the way we think and feel.

In this section of moral knowledge, there are three aspects that are highlighted as the desired goal of character education, namely moral awareness, knowledge of moral values, and determination of perspective. Whereas in the section on moral feelings, the aspects that were emphasized were conscience, empathy, and humility. And moral action are three aspects ofemphasized, namely competence, desires and habits.

According to Lickona, education that is directed at these three components will make a person objectively good, not only for oneself, but also for society as a whole. The terminology of character education was introduced since the 1900s. Thomas Lickona is considered to be the advocate, especially when he wrote a book entitled The Return of Character Education and later his book, Educating for Character: How Our 
School Can Teach Respect and Responsibility. Character education does not just teach children what is right and wrong, but more than that character education instills habits (habituation) about what is good so that students understand, are able to feel (affective), and want to do good (psychomotor) (Daryanto \& Suryatri, 2013). So, character education carries the same mission as moral education or moral education.

Moral education is not a new idea. In fact, moral education is as old as education itself. Throughout history, in countries around the world, education has had twogoals big, namely to help children be smart and to help them become better again (Thomas Lickona, 2013). When people think that morality is something that is constantly changing, relatively individually, depending on the situation, and is personal, schools then withdraw from the entral role as moral teachers that they once held. As a social institution, schools must regulate moral behavior, schools require students to obey teachers, prohibit them from fighting, punish them for cheating, and so on.

Thomas Lickona cites the viewpoint of Mercy Coolege psychologist Sidney Callahan in his book, In Good Conscience: Reason andEmotion in Moral Decision Making, that much ofmoral thinking our creativesprings from emotionally laden experiences.moral revolution An importanthas begun with a felt empathy forgroups previously un-consideredsuch as slaves, women, workers, children, people with special needs and so on (Thomas Lickona, 2013).

Realizing that being intelligent and having good behavior are not thething same, policymakers since the time of Plato have made a policy regarding moral education which is deliberately made as a major part of school education. They have educated the character of society equal to intelligence education, educated politeness equal to literacy education, educated the same virtues as science education. They have also tried to form a society that can use their intelligence to benefit both society and for themselves as part of a society that builds alife better.

Character Education of Ki Hajar Dewantara and Thomas Lickona Ki Hajar Dewantara further emphasized that education is a guide in the life of growing children. This means that thelife growing of these children lies beyond the ability or will of the educators. To realize his ideas about education, in the implementation of education, Ki Hajar Dewantara used the "Among System" as the embodiment of his conception of placing children at the center of the educational process. In the Among System, every teacher (pamong) as a leader in the education process is requiredhave the following toattitude: Ing Ngarsa Sung Tuladha, Ing Madya Mangun Karsa, Tutwuri Handayani.

According to Thomas Lickona, good character scheme starts from the knowledge of good (moral knowing), and then generate commitments (intention) to good(moralfeeling), and finally actually do good(moralaction).The following is a comparison of theeducation characterof the two world education figures. Character education in Islam can be understood as an effort to instill the doctrine of normative values that determines the behavior of the tutor who educates in accordance with the demands that make every human being have character. The balance of the elements of creativity, taste and intention that cannot be separated, shows that Ki Hajar Dewantara does not see education as a process of only transmission or transfer of knowledge (transfer of knowledge) but at the same time education is also a process of value(transformationtransformation of value). Meanwhile, according to Thomas Lickona character education is a serious effort that involves three aspects in students including cognitive, affective, and psychomotor. By knowing later students will feel, 
and then there will be a willingness to actually do actions that reflect a noble character (good character).

Therefore, how to form good and effective character according to Ki Hajar Dewantara and Thomas Lickonamust involvethree each of the aspects. And these three aspects will be summarized in the table following:

\begin{tabular}{|c|c|c|}
\hline $\begin{array}{l}\text { The Concept of } \\
\text { Education of } \\
\text { Character }\end{array}$ & Ki Hajar Dewantara & Thomas Lickona \\
\hline $\begin{array}{l}\text { Transformation of } \\
\text { the }\end{array}$ & $\begin{array}{l}\text { Education Tripusat, namely: } \\
\text { 1. Family } \\
\text { 2. School } \\
\text { 3.Society }\end{array}$ & $\begin{array}{l}\text { Moral Knowledge: } \\
\text { 1. Moral Awareness } \\
\text { 2. Knowing } \\
\text { Moral values } \\
\text { 3. Determining } \\
\text { thePerspective }\end{array}$ \\
\hline Internalization & $\begin{array}{l}\text { Cultivation of Normative } \\
\text { Values: } \\
\text { 1. Habit } \\
\text { 2. Formation } \\
\text { 3. Cultivation }\end{array}$ & $\begin{array}{l}\text { of Moral Feelings: } \\
\text { 1. Conscience } \\
\text { 2. Empathy } \\
\text { 3. Humility }\end{array}$ \\
\hline Transinternalization & $\begin{array}{l}\text { Among Methods: } \\
\text { 1. Giving Examples } \\
\text { 2. Teaching } \\
\text { 3. Commands, coercion and } \\
\text { punishment } \\
\text { 4. Behavior } \\
\text { 5. Birth andExperience } \\
\text { Inner. }\end{array}$ & $\begin{array}{l}\text { Moral Actions: } \\
\text { 1. Competence } \\
\text { 2. Desire } \\
\text { 3. Habits The }\end{array}$ \\
\hline
\end{tabular}

system of among has been known for a long time in the Tamansiswa environment, is a way of educating which is applied with the intention of obliging the natural nature of its students. The way to educate that must be applied is to support or provide guidance and support the children to grow and develop on their own nature. Among this system puts education as a tool and condition for children to live alone and be useful for society. Teaching for Tamansiswa means educating children to become human beings who are independent in mind, independent in mind, independent in their energies.

The teacher should not only provide good and necessary knowledge, but must also educate the students, so that they can seek themselves that knowledge and use it for public charity.knowledge. That good and necessaryis useful for both physical and mental needs in living together. Each teacher, in the mindset of Ki Hajar Dewantara, is the servant of the child, the servant of the student, not the ruler of the children's souls. To increase the participation of students in implementing character education and becoming a good Muslim person, students must have good initiatives to maintain and foster themselves and their environment so that they can avoid efforts and influences of culture that are contrary to Islamic values (Angga Meifa Wiliandani, 2013).

The implementation of character education according to the two characters must be really carried out, by providing character cultivation good so that moral knowledge can look good, then instilling good character understandings so that the feelings Moral of each student can be organized as best as possible and can apply / 
produce good moral actions in accordance with the teachings of Islam. Selfdevelopment is an habituation that aims to instill good habits in students, habituation that is carried out continuously will become a character in a student. This selfdevelopment is a means of habituation, cultivation, as well as monitoring in cultivating character according to Islamic values that have been in understanding and theory taught. Character education is absolutely essential to be applied into order restore the character of the Indonesian nation which has begun to erode and even disappear along with the development of the times.

\section{CONCLUSIONS}

Character education transformation is a process of change gradually so that it reaches the ultimate stage, changes are made by responding to the influence of externalelements and internal. In Ki Hajar Dewantara's educational concept, he conveyed several educational concepts to realize the achievement of educational goals, one of which is through the Tri Education Center: family, school and community. The balance of these three things is crucial to the success of an educational goal. Meanwhile, according to Thomas Lickona, there are various moral knowledge that we can use when we are faced with moral challenges in life. The following three moral knowledge are expected to be the goals of character education: moral awareness, knowing moral values, and determining perspective. The internalization of character education is a process or way of instilling doctrine or normative values that determine educational behavior in accordance with the guidance towards the formation of a characterized national personality. This provides the principle of learning theory and practice of understanding, feeling, and lan nglakoni. This means that to carry out character education, understanding must be embedded and can feel something that is learned and then can implement it in real behavior. According to Thomas Lickona, the emotional side of this character, as well as the intellectual side, is open to development by schools and families. The following moral emotional aspects will focus our attention when we seek to teach about good character such as conscience, empathy, and humility.

\section{ACKNOWLEDGEMENTS}

Thank you for participant in this research and teacher for help in this research.

\section{AUTHOR CONTRIBUTION STATEMENTS}

First author had contribution for collecting data in this research. Corresponding author was a corresponding person with editor, from submission until publish for this article. Another authors help to improve this research paper before submit to journal.

\section{REFERENCES}

Amri, S., Ismawati, T., \& Armila, A. (2020). Studi Analisis Nilai Nilai Pendidikan Karakter Perspektif Syech Muhammad Khudhari Bek dalam Kitab Khulashah Nurul Yakin. Attractive: Innovative Education Journal, 2(2), 77-88. Google Scholar

Angga Meifa Wiliandani, Bambang Budi Wiyono,\& A.Yusuf Sobri, Implementasi Pendidikan Karakter dalam Pembelajaran, Jurnal Pendidikan Humaniora, Vol. 4 No. 3, 132-142. Google Scholar

Asmani, Jamal Ma'ruf. 2013, Buku Panduan Internalisasi Pendidikan Karakter di Sekolah. Yogyakarta: Diva Pres. Google Scholar 
Amrizal, A., Subandi, S., \& Fadillah, M. K. (2020). Effektivitas Taklim Remaja Islam Masjid dalam Membentuk Karakter Remaja di Era Industri 4.0 di Masjid Riyadus Sholihin. Attractive: Innovative Education Journal, 2(1), 126-132. Google Scholar

Cahyono, H., Suhono, S., \& Khumairo, A. (2018). Pendidikan Karakter Bagi Pelaku Pedofilia (sebuah Strategi dalam Mengatasi Amoral). JMKSP (Jurnal Manajemen, Kepemimpinan, dan Supervisi Pendidikan), 3(1). http://dx.doi.org/10.31851/jmksp.v3i1.1519

Daryanto \& Suryatri Darmiatun. (2013). Implementasi Pendidikan Karakter di Sekolah. Yogyakarta : Gava Media. Google Scholar

Gunawan, Ari H. 2010. Sosiologi Pendidikan. Jakarta : Rineka Cipta. Google Scholar

Gunawan, Heri. 2014. Pendidikan Karakter, Konsep dan Implementasi. Bandung, Alfabeta. Google Scholar

Harahap, M. T., Hasyimsyah, H. H., \& Suwardi, S. S. (2017). Communication ethics Ibn Miskawaih and its relevance to the solving of moral problems in Indonesia. International Journal on Language, Research and Education Studies, 1(1), 119-129. Google Scholar

Indrijati, H. (2017). Juvenile delinquency of senior high school students in Surabaya, Indonesia. Int. Sch. Sci. Res. Innov, 11, 184-188. Google Scholar

Jumadi, J., \& Nurlela, N. (2017, August). The Character Education and Social Conflict Phenomenon that Leads to Student Collective Violent Behavior. In 8th International Conference of Asian Association of Indigenous and Cultural Psychology (ICAAIP 2017). Atlantis Press. https://dx.doi.org/10.2991/icaaip17.2018.53

Kristiawan, M., Ahmad, S., Tobari, T., \& Suhono, S. (2017). Desain Pembelajaran SMA Plus Negeri 2 Banyuasin III Berbasis Karakter Di Era Masyarakat Ekonomi ASEAN. Jurnal Iqra': Kajian Ilmu Pendidikan, 2(2), 403-432. https:// doi.org/10.25217/ji.v2i2.178

Lickona, Thomas. 2013. Mendidik Untuk Membentuk Karakter : Bagaimana Sekolah Dapat Mengajarkan Sikap Hormat dan Tanggung Jawab. ter. Juma Abdu Wamaungo. Jakarta: Bumi Aksara. Google Scholar

Manshuruddin, M., Rozana, S., \& Abrianto, D. (2019). character education in modern islamic boarding schools: a model from indonesia. European Journal of Social Sciences Studies. http:/ / dx.doi.org/10.46827/ejsss.v0i0.617

Muthoifin, M., \& Jinan, M. (2015). Pendidikan Karakter Ki Hadjar Dewantara: Studi Kritis Pemikiran Karakter Dan Budi Pekerti Dalam Tinjauan Islam. Profetika: Jurnal Studi Islam, 16(2), 167-180. https:/ / doi.org/10.23917/profetika.v16i2.1852

Oudeyer, P. Y., Gottlieb, J., \& Lopes, M. (2016). Intrinsic motivation, curiosity, and learning: Theory and applications in educational technologies. In Progress in brain research (Vol. 229, pp. 257-284). Elsevier. https:// doi.org/10.1016/bs.pbr.2016.05.005

Pérez, L. (2016). Technology, curiosity and utility in France and in England in the eighteenth century. In Science and spectacle in the European enlightenment (pp. 3754). Routledge. Google Scholar

Prasetiawati, P. (2018). Integrated character education model sebagai alternatif solusi mengatasi degradasi moral pelajar Indonesia. Jurnal Ilmiah Dikdaya, 8(1), 177186. http://dx.doi.org/10.33087/dikdaya.v8i1.99

Salahudin, A., \& Alkrienciehie, I. (2013). Pendidikan karakter: pendidikan berbasis agama E budaya bangsa. Pustaka Setia. Google Scholar 
Suparlan, H. (2015). Filsafat pendidikan Ki Hadjar Dewantara dan sumbangannya bagi pendidikan indonesia. Jurnal Filsafat, 25(1), 56-74. Google Scholar

Yudabangsa, A. (2020). Pengembangan Kesadaran Keberagamaan dan Pembentukan Karakter Siswa Melalui Pembiasaan Shalat Dhuha'. Attractive: Innovative Education Journal, 2(1), 117-125. Google Scholar

Copyright Holder :

(C) Ansawan, A,. (2020).

First Publication Right :

(C) IJoASER (International Journal on Advanced Science, Education, and Religion)

This article is under:

CC BY SA 